\title{
On the Landscape Composition of Traditional Village in Huizhou District - A Case Study in Qizili Village
}

\author{
Cheng Peng ${ }^{1}$, Xiao Siyi ${ }^{2}$, Li Yunzhang ${ }^{2}$, and Bi Zhongsong ${ }^{1,2 *}$ \\ ${ }^{1 *}$ College of Architectural and Engineering \& Research Centre of Huizhou Architecture, Huangshan University, 245041 Huangshan, \\ China \\ ${ }^{2}$ College of Architecture and Environment, Sichuan University, 610065 Chengdu, China
}

\begin{abstract}
The landscape features of traditional villages displayed in the Huizhou District were formed in a specific environment gradually. It was the result of the comprehensive effects of natural, historical, social, and cultural factors. This study took Qizili Village as an example and sorted out the composition and current situation of its natural landscape and human landscape. To refine the proper composition model of Qizili Village, we analyzed the landscape features from the perspectives of the natural environment, layout planning, traditional architecture, environmental elements, and traditional culture. Finally, we concluded the landscape connotation of Qizili Village.
\end{abstract}

\section{Introduction}

Traditional villages refer to ancient villages that have existed for a long period. Since these villages have strong social and economic values due to their enrichment of natural and cultural resources, they need to be protected and maintained ${ }^{[1]}$. China has attached more and more importance to the protection of traditional villages since the 21 st century. However, traditional villages are still in danger of vanishment caused by continuous damages during the process of Chinese modernization, urbanization, and new rural construction ${ }^{[2]}$.

Huizhou was an administrative division concept. It was once named Xin'an County in the Han Dynasty, and Kuanzhou in the Tang Dynasty. It was not until the Northern Song Dynasty, the emperor Huizong renamed Xin'an as Huizhou under his emperor title. The name Huizhou was used ever since. Ancient Huizhou governed six counties: She County, Yi County, Jixi, Xiuning, Qimen, and Wuyuan. The early villages were mainly formed by scattered settlements of local Shanyue indigenous peoples. The villages were initially formed due to the clan's migration of the Central Plains since Eastern Jin, late Tang, and Southern Song Dynasties. The villages came to a large scale at the beginning of the Ming Dynasty and reached the peak of prosperity in the middle of the Qing Dynasty ${ }^{[3]}$. It decayed gradually at the end of the Qing Dynasty.

The traditional villages in Huizhou are one of the typical representatives of ancient Chinese villages ${ }^{[4]}$. Historically, the indigenous inhabitants were mainly of the same clan or the same ethnic group. Additionally, the inconvenient transportation based on the mountainous geographic feature in southern Anhui led to the slow economic development in Ancient Huizhou. This economic disadvantage prevented the village from linking with the outside world. However, in the era without the advocation of active protection of local culture, the lagging development helped the inheritance of the local cultural resources. Therefore, the ancient villages were almost unchanged. In recent years, to the intense attention from the local governments, a wealth of traditional village resources remains the original appearance in Huizhou District with the rapid local economic progress. So far, most of these retained traditional villages are in living status. The landscape of traditional villages is preserved intact with a rich composition content (Fig.1).

When looking at the traditional villages, there are three layers: the outer layer refers to the natural mountains and rivers surrounding, the middle layer refers to the village and its spatial environment, and the inner layer refers to the village architectural details, such as buildings, bridges, pavilions, etc. All three layers are of strong Hui-style characteristics. The purpose of this study is to find the proper landscape composition mode of a traditional village based on the factors of nature, history, society, and culture ${ }^{[5]}$. To do so, we selected a representative village Qizili in Huizhou District. Qizili Village is located in the northeast of Shexian County, Anhui Province. It stays between the subtropical warm and humid monsoon climate zone. Thus, the climate conditions with four distinct seasons contribute to the lush vegetation outside the village, and intact mountain forest vegetation. 846 households with a population of 2631 people live in the village. Since Qizili Village was the transportation hub on the road of Ancient HuiHang Road, it linked Shexian County in Ancient Anhui Province and Chunan County in Ancient Zhejiang Province. Thus, Qizili Village played a crucial role in the

"Corresponding author: bzs@stu.scu.edu.cn 
trade between Ancient Anhui Province and Ancient Zhejiang Province. It contributed to the economic development of both places ${ }^{[6]}$. Meanwhile, the above natural and social factors promoted the featured characteristics of the landscape in Qizili Village.

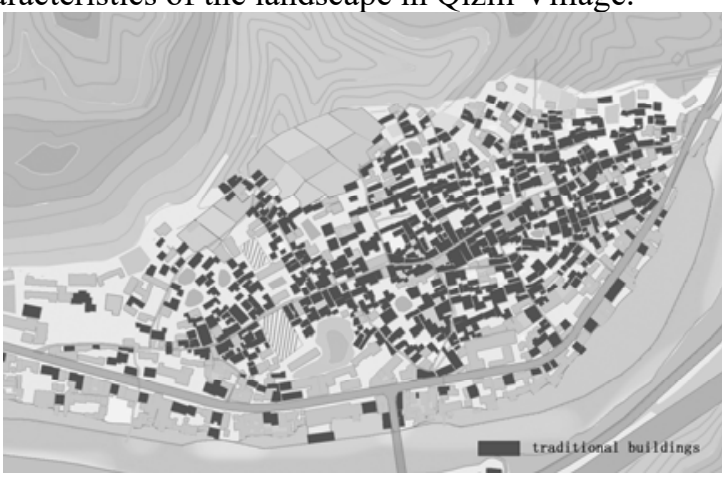

Fig. 1 Distribution map of traditional buildings

The research on the composition and current situation of Qizili Village helps to deepen recognization of the natural and human landscape of Huizhou traditional villages. This study provides a basis for how to preserve the natural environment, village pattern, architectural style, and traditional culture in traditional villages. The continuation of traditional village helps to improve the infrastructures and public facilities. By providing new ideas for the protection and development of traditional villages, it is beneficial for the living standards and the sustainable development of traditional villages.

\section{Landscape composition of traditional villages}

The precondition of the recognition of landscape features is to determine a reasonable classification of landscape types. This paper draws on the related content of village characteristic analysis and value evaluation in the Basic Requirements for the Preparation of Traditional Village Protection and Development Planning issued by the Ministry of Housing and Urban-Rural Development of the People's Republic of China to classifies the site investigation results of Qizili Village. We established two major aspects of a traditional village: nature and humanity. Specifically, it includes five categories of the natural environment, planning layout, traditional architecture, environmental elements, and traditional culture. The subcategories of the natural environment include village terrain, landform, climate, and vegetation. The subcategories of planning layout include village form, scale, structure, and layout. The subcategories of traditional buildings include building types, plane forms, structural types, materials, roofs, gables, Decorations, and other small items. The subcategories of environmental elements include street paving, pavilion walls, water wells, ponds, bridges, and other small items. The subcategories of traditional culture include surname beliefs, language customs, opera crafts, and other small items ${ }^{[7]}$. Based on the above classification, the landscape system that constitutes the traditional villages in Huizhou is complex and diverse, covering all aspects of nature and humanities, material, and non-material. The landscape system contains the characteristics of the traditional village landscape system in Huizhou completely.

\section{Landscape characteristics of Qizili Village}

\subsection{Natural environment characteristics}

Qizili Village, located in the eastern mountainous area of Shexian County, sits in the mountain valleys with distinct four seasons. The geographic feature of lush forest vegetation is favorable to form an excellent ecological environment. The types of landforms are complex and diverse. The local geological structure shows obvious folds and fractures. The soil is mainly mountainous red and yellow soil, suitable for the growth of various economic crops such as tea, mulberry, and chrysanthemum. Surrounded by mountains and rivers, Qizili Village maintains a relatively primitive ecological environment. The four mountains, including Hengyan, Wangyan, Ma'an, and Tanghou, Qizili, surround the village. The Changyuan River flows from east to west through the south of Qizili Village with an outer arc shape. Three smaller rivers in the village merge into the Changyuan River (Fig.2). It is a typical Taoyuan-style village in Huizhou District. The site selection of Qizili Village follows a relatively closed spatial pattern with mountains, forests, land, and water. The terrain is high in the north and low in the south. It is a true portrayal of the ideal landscape pattern consistent with the ancient cultural connotation that people should choose a lucky place to live ${ }^{[8]}$. The landscape of "mountain-water-fielddwelling" also highlights the characteristics of the overall environment of Qizili Village.

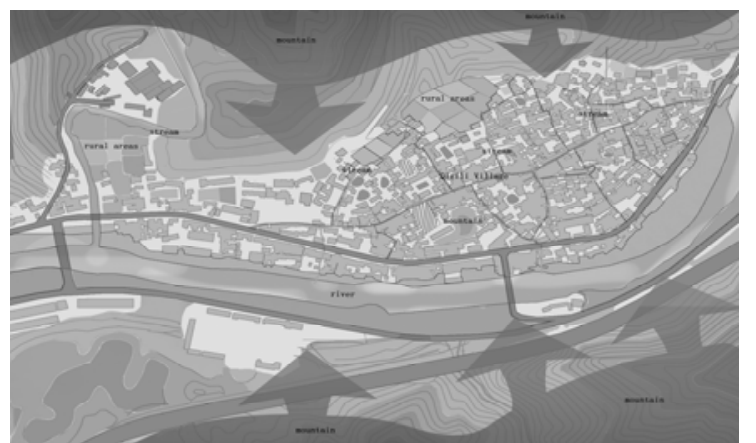

Fig. 2 Landscape characteristics of Qizili Village

\subsection{Layout planning characteristics}

Qizili Village has experienced a long history with an ancient name of Xizili. It was not until the Song Dynasty that the name had been changed to Qizili. Qizili Village reached its development peak during the Shaoxing period of the Southern Song Dynasty. Due to the increasingly dense population of the village and the limited space for survival and development, villagers began to move out to build new ones. Thus, the size of the village finally stabilized. Ancient Qizili Village had three parts: the village head, the middle street, and the village end. The 
village roads were tortuous, the steps were undulating, and the vertical space was full of changes. The terrain dropped from the east of the village to the west is nearly 10 meters with four-level stacking streets. The streets were flat, and people walked on them without the feeling of heights. The ancient village was built following the situation, using blocks to adjust the height of the foundation, forming a patchwork skyline. When entering the village from Shuikou, guided by roads, space formed three stages of semi-closed-open-closed. The ancient village took Dalu Street as the axis, with the alleys evenly distributed across the north and south as the front, and the traditional buildings as the center. The whole village was the layout as a fishbone, forming a village pattern of three streets and twenty-four alleys (Fig.3). Road pavilions and public activity spaces met the needs of transportation and communication. Nowadays, Qizili Village has a clear structure, rigorous overall layout, and reasonable functional layout, reflecting the form and development mode of traditional Chinese ancient village planning and construction $^{[9]}$.

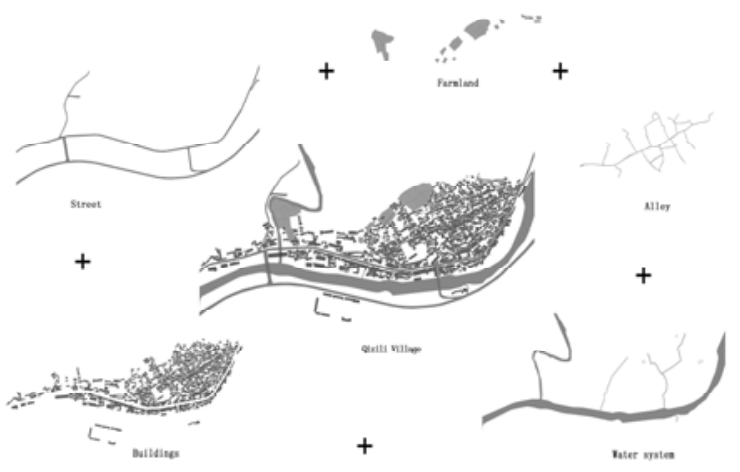

Fig. 3 Layout planning characteristics

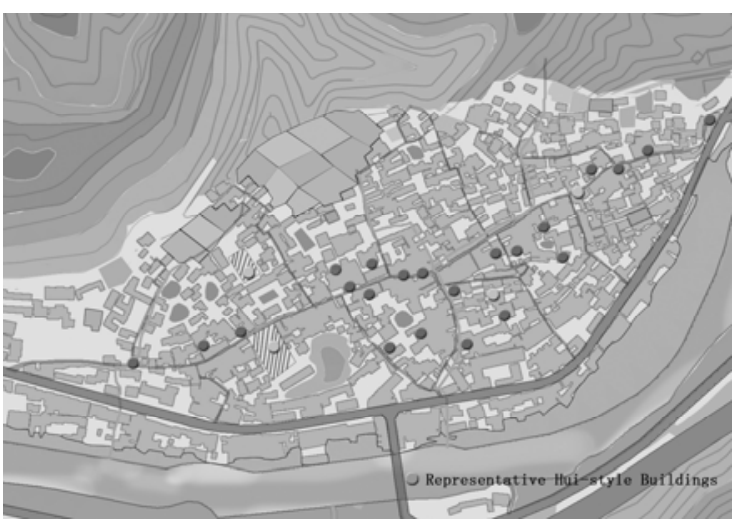

Fig. 4 Important traditional building

\subsection{Traditional architectural characteristics}

The gathering of ethnic groups in Qizili Village decided local architectural distribution. Ancestral halls and residential buildings were typically traditional buildings in Qizili Village were. There were 22 representative buildings, such as Huaiyuan Temple, Mingyi Hall, Zhisan Pavilion, Funding Hall, and others (Fig.4) in the village.

The characteristics of these buildings included harmonious size, a suitable scale, and the elegant color of the walls and tiles. Most of these buildings faced southwest. A typical Huizhou architectural form tended to be symmetrical layout with three rooms taking the patio as the centre. The centre was used as the main hall, with rooms on both sides, and the stairs were around the main hall (Fig.5). The structure adopted the beam-lifting type, with wooden pillars and wooden beams inside for load-bearing, brick exterior walls, and horsehead gables for isolation. The roofs of Huizhou architectural buildings were usually double-sloping or partial single-sloping with long and protruding eaves to prevent rainwater from splashing into the house as well as the "sit-bucket style" horse head gables to isolate fires and theft. Three kinds of carving with landscape themes: stone carving, wood carving, and brick carving were integrated naturally to highlight Hui-style architecture (Fig.6).

Compared with the square bricks mostly used in other areas of Huizhou, the buildings mostly used bluestone slabs in Qizili Village. The villagers made full use of bluestone slabs as most materials in the construction process due to the abundant stones in the local area.

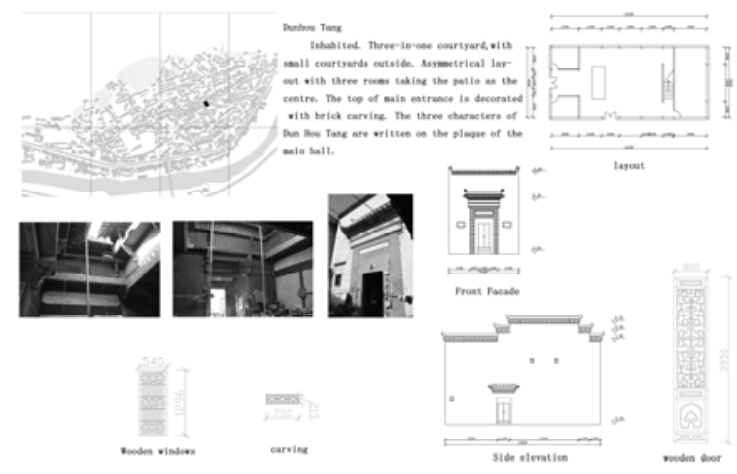

Fig. 5 Mapping of typical Hui-style building Dunhoutang

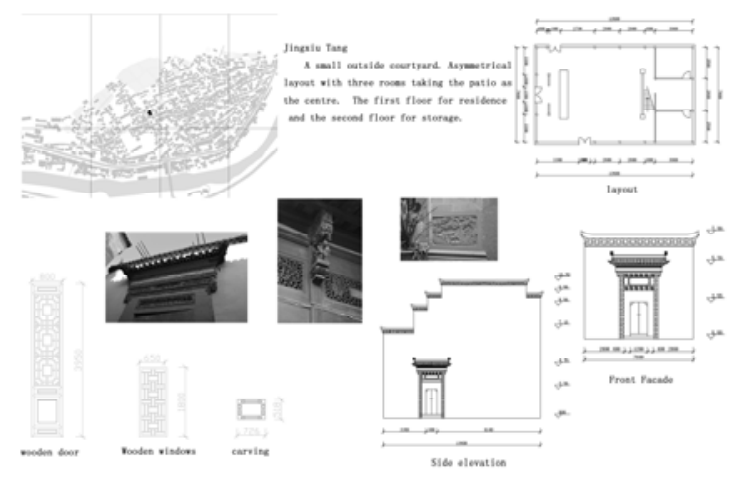

Fig. 6 Mapping of typical Hui-style building Jingxiutang

\subsection{Environmental elements characteristics}

Over 40 historic streets and alleys paved by bluestone slabs were built in Qizili Village during the Ming and Qing Dynasties (Fig.7). The main street was the official road of Yulingguan Ancient linking Anhui and Zhejiang. Hence, it was once the important channel for the exchange of materials and business of two commercial centres: Huizhou and Jiangnan. The Qixi Ancient Road in the north of the village led to Longchuan, Jixi, which was 
historically the main road for outsourcing the villagers' living materials. The Siyongtang Bridge was five miles upstream of the village. The south village saw the other six stone bridges, such as Shixiang Bridge and Huisheng Bridge. Since most villagers are mainly named Wang, three locust trees planted outside the Shuikou Pavilion in the west of the village imply that the officials named Wang were major roles in the officialdom. Wells and ponds scattered in the village. The existing Sangen Well, Jianggong Well, Houshan Well, Xitan Pond, Xujia Pond, Qianjie Pond, Gecko Pond are still providing villagers with drinking water and fire- fighting water nowadays.

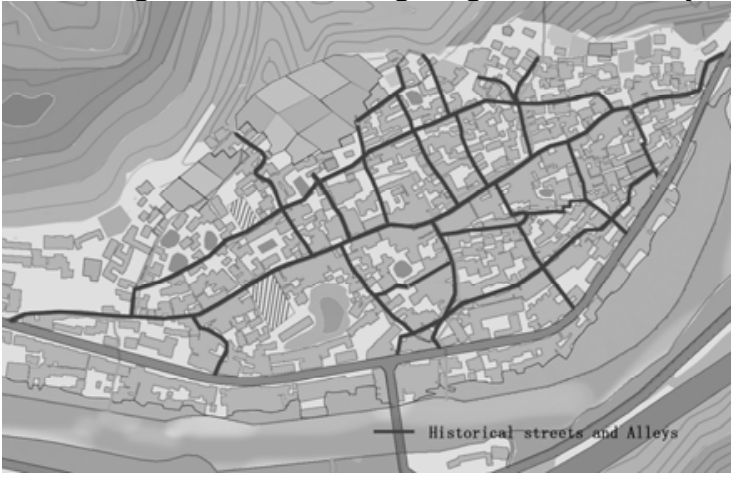

Fig. 7 Distribution map of streets and alleys

Historical environmental elements in Qizili Village were various (Fig.8), most of which were based on actual functions and uses. It fully reflected the simple life concept of the working people in the ancient mountainous areas. It showed the ecological concept of adapting measures to local conditions and making full use of the natural environment.

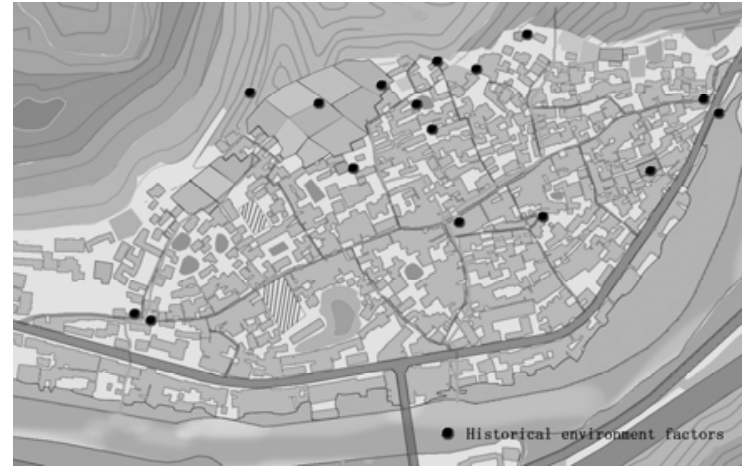

Fig. 8 Distribution map of other environmental elements

\subsection{Traditional cultural characteristics}

In the historical process of the development of Huizhou, each village formed a unique village culture manifested in clan etiquette, opera and ballads, and celebration customs ${ }^{[10]}$. Connecting the ancient Shexian County in Anhui Province to the west with Chun'an County in Zhejiang Province to the east, Qizili Village became a critical node of Huizhou's external relations. The combined effect of Huizhou and Jiangnan culture promoted the formation of the distinctive landscape in the long history of development as well as the unique production lifestyles and customs. These factors encouraged the village to form its unique cultural characteristics. With a population of over $80 \%$, villagers in Qizili Village were named Wang. The inheritance of clans from generation to generation by the gathering of clans made it possible for the production and preservation of a large number of Huizhou documents. The representative documents included "Wang Family Genealogy", "Six Dragon Map", various medical books, and ancient books on family genealogy (Fig.9). The interweaving of culture led to a variety of custom activities in Qizili Village. For instance, measles lantern was a unique local traditional custom that was a lantern festival based on children's local operas. Any child who participated in this event would not suffer from measles for one year. Hence, the main participants were children (Fig.10). The Huizhou folk songs handed down in the village are rich in content and diverse in genres, such as chants, folk songs, minors, Buddhist and Taoist songs. 32 folk songs were written. Golden silk amber candied dates, a famous spot in Shexian County since the Ming and Qing Dynasties, still has production in Qizili Village. The ancient craftsmanship of candied dates has successfully passed on in Qizili Village. Other traditional festivals, such as welcoming the dragon lantern in the first month of the lunar calendar, sending the plague God in February, and celebrating the harvest on October 15, also spread to today.

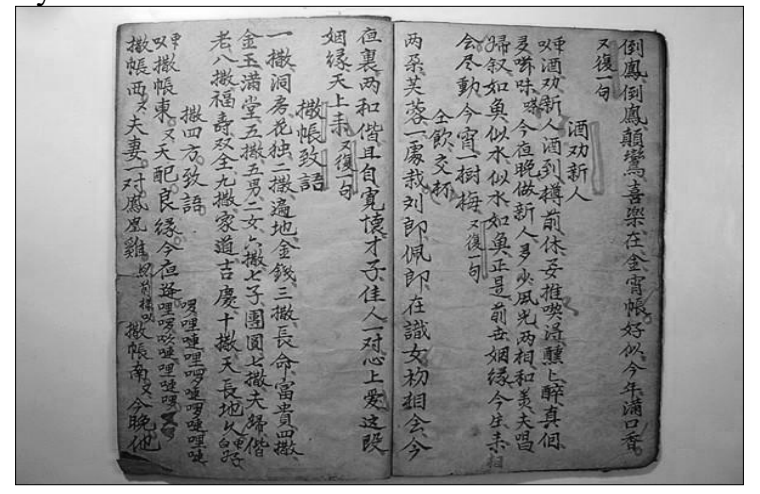

Fig. 9 Folklore activities notebook

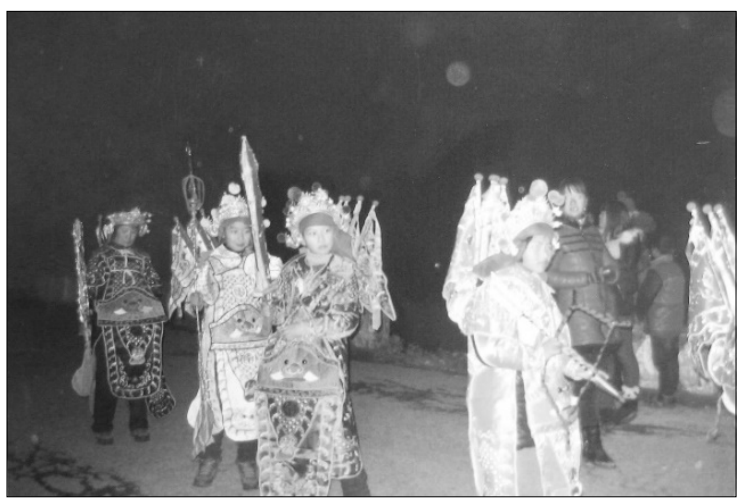

Fig. 10 Measles lantern activities

\section{Conclusion}

This study took Qizili Village as an example and sorted out the composition and current situation of its natural landscape and human landscape. We focused on the characteristics of the Qizili Village landscape from the 
five major aspects of the natural environment, planning layout, traditional architecture, environmental elements, and traditional culture that constitute the landscape. The excellent natural environment of Qizili Village thanked the surrounding mountains and water. The entire village presented a reasonable layout and clear structure showing a high level of planning and construction. The village preserved a relatively complete and unique Huizhou traditional style with a relatively perfect layout and ancient buildings. The environmental elements with strong regional characteristics were diverse in forms as well as abounding in Qizili Village. Thus, the traditional villages in Huizhou represented by Qizili Village presented unique landscape characteristics in terms of village site selection, spatial layout, streets and alleys, individual buildings, and village culture.

Qizili Village provides a real historical example for understanding and studying the landscape features of Huizhou villages. Hence, this study contributes to the extant research by a distinguished example. The proper landscape composition of Qizili helps to improve the local environment, increase local infrastructure and public facilities, improve the living standards of villagers, and enable the sustainable development of traditional villages.

\section{Acknowledgements}

This study was funded by Special Funding Project of Innovatively Provincial Construction in Anhui Province (Project No.2020XZX001). Anhui Education of Department Humanity and Social Science Research Project "Research on the Landscape Features of Traditional Villages along Huizhou Ancient Road from the Perspective of Cultural Routes" ( Project No. SK2020A0468 ). MOE (Ministry of Education of the People's Republic of China) Youth Fund Project of Humanities and Social Sciences (Project No.18YJC850002). Bidding Project of Key Research Base of Humanities and Social Sciences in Colleges and Universities of Anhui Province (Project No. SK2015A170). "10303 Plan of Huizhou Research Talents Training" Project of Huangshan Social Science Federation.

\section{References}

1. Huang Chenglin, Preliminary Research on Huizhou Cultural Landscape.Geographical Research. 2000,19(3):257-263

2. Wu Xiaolin, Chen Ansheng, Wan Guoqing. World Cultural Heritage-Discussion on the Characteristics of Ancient Villages in Southern Anhui. Journal of Architecture. 2001(8):59-61.

3. Lu lin, Jiao Huafu, Cultural content of Huizhou architecture. Journal of Nanjing University. 1995(2):163-171.

4. Liu Peilin. Conservation and development of traditional settlements based on the concept of landscape gene integrity. Economic Geography. 2009,9(10):731-736.

5. Zhang Xichen, Hao Jingxin. Research on Laneway Landscape of Traditional Settlement in Southern Anhui.Journal of Jiangnan University.2002,1(2):179183.

6. Chen Wei. The formation, development, and evolution of Huizhou vernacular architecture and traditional settlements. Huazhong Architecture. 2000,18(3):126-127.

7. Fang Xiansong. On the effect of ancient village landscape environment on the development of rural tourism. Shanxi Architecture.2010, (6):24-25.

8. $\mathrm{Hu}$ Zui, Liu Peilin. Spatial characteristics of landscape genes of traditional settlements in Hunan Province. Acta Geographica Sinica. 2013,68(2):219231.

9. Li Guo. Research on the identification of traditional settlement landscape characteristics in Wuling Mountain based on integrated protection. Huazhong Agricultural University, 2017.

10. Zou Weihan. Analysis of landscape genes of traditional settlements along the Shu Road (South Shaanxi). New architecture, 2018(6):38-41 